\title{
分子線エピタクシー $\mathrm{GaAs}$ 薄膜への ドーピング効果
}

$\begin{array}{llll}\text { 東京工業大学 } & \text { 永 } & \text { 沼 } & \text { 充 } \\ \text { 東京工業大学 } & \text { 高 } & \text { 橋 } & \text { 清 }\end{array}$

\section{1. まえがき}

極好薄いエピタキシャル層を均一に形成する新し い方法上して，分子線法が最近注目さ机ている ${ }^{(1) ~(4) 。 ~}$ 筆者らは，すでに分子線法による $\mathrm{GaAs}$ 薄膜のエピ タクシー成長については本論文誌 ${ }^{(5)} て ゙$ 報告した。一般 亿真空蒸着は，不純物をドープしながら結晶成長を行 なう場合には有利な力法である。つまり，ドーパント 用の蒸発源を没就ての温度を制御するだけでよいか らである。しかし，GaAs 蒸着膜汇関しては不純物の 同時蒸着によるドーピングの報告はほとんどない。を の理由は，従来の真空蒸着では母体結唱の結晶性が悪 く、ドーピングの勃果が顕著に現われなかったためで あると思われる。

前報で分子線法を用いれば舟体結晶の結晶性がかな り良好になるととがわかったので，本論文では分子線 法による GaAs エピタキシャル膜の不純物ドーピング を中心として報告し，あわせて不純物の付着係数につ いて一般的に論ずる。

\section{2. 付着係数}

分子線法による結晶成長では，真空中を飛来してき た分子あるいは原子が基板に皘み重なって薄膜を形成 する。したがって，飛来分子の基板あるいは成長層へ の付着係数か㔈膜の成長に大きく影響する。基板への 付着保数は薄膜の成長の初期にのみ重要で，第 1 層が 形成されてしまうか，あるいは成長核が合体して基板

Impurity Doping Effect of Molecular Beam 'Epitaxial GaAs Films. By M. NAGANUMA, Associate \& K. TAKAHASHI, Member (Faculty of Engineering, Tokyo Institute of Techno. $\log y$ ).

永沼 充: 准貝, 東京工業大学

高楿 清: 正貝, 宋宗工業大学工学部電子物理工学科
表面が扔括いつくされてしまえば考えなくて良い。ま た本論文で扱う GaAsのホモエピタクシーの場 合に は，基板と成長層は同じであるから成長層への付着係 数を考えれば良い。GaAs の母体結晶の成長について は，Ga之Asの付着係数についてすでに報告されてい る(6)。乙れによるよ分子線法に上る GaAs 結晶の成辰 は, GaAs 成長首への As の付着係数の吸着 $\mathrm{Ga}$ 密度 恢存性に上っている。GaAs 表面へのAs の付着係数 は活とんど零であるが，表面に Ga が存在する場合に はこれが雾でなく有限の値をむつ。すなわち，GaAs 表面上にAs のみが過鄱倠積するととはない。一方 $\mathrm{Ga}$ の付着係数は $\mathrm{GaAs}$ 表面上で有限な值をもち, 適 当な基板温度笵囲では温度に対して指数関数的に变化 する。すなわち，GaAs 表面に Ga のみ堆皘するこ之 仙可能である。また $\mathrm{Ga}$ 上へのAs の付着係数は 〜 である。したがって，過剩な $\mathrm{Ga}$ が堆皘しない程度に Asを Gaに対して余分に供給してやれば，Ga と結 合し得なかった As は脱着してしまい，化学量諭比の GaAs を形成することができる。これからわかるよう に，結晶成誛の速度は供給する $\mathrm{Ga}$ 分子線の量によっ て決まる。

不綎物の付着係数は次の二つの点で重要で占る。字 ず，第 1 にはドープしたい不純物を結晶中に混入でき るかどうかというととであり，第2にはできるだけ湿 入させたくない残留がス中の不純物がどの程度影響を 及ぽすかといら点からである。一般に標準状惎におい て結晶性の物筫は，付着係数之単体の平衡蒸気死の間 に同じ傾向が見られる。つまり，蒸気圧か高く蒸発し やすい物質は付着係数が小さい。今まで報告されて いる $\mathrm{GaAs}$ 上への種々の原子, 分子の付着係数第 1 表に示す。ドーピング用不純物については第 4 章で述 
第，1表 GaAs 上への種々の原子，分子の 付着係数

Table 1. Sticking coefficient of several atoms and molecules on GaAs.

\begin{tabular}{|c|c|c|}
\hline & 付语 保数 & 温 度 \\
\hline$A s^{(\theta)}$ & 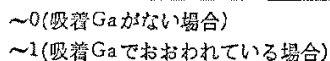 & $\left(560^{\circ} \mathrm{C}\right)$ \\
\hline $\mathrm{Si}, \mathrm{Ge}, \mathrm{Sn}^{|\mathrm{E}\rangle}$ & $\sim 1$ & $\left(560^{\circ} \mathrm{C}\right)$ \\
\hline $\mathrm{Mg}^{(8)}$ & $10^{-5}$ & $\left(560^{\circ} \mathrm{C}\right)$ \\
\hline $\mathrm{Cd}, \mathrm{Zn}^{(23)}$ & $\sim 0$ & $\left(500^{\circ} \mathrm{C}\right)$ \\
\hline \multirow[t]{3}{*}{$\mathrm{O}_{2^{\prime 15)(16)}}$} & $10^{-4}$ (11ij) & \\
\hline & $10^{-5}(111)$ & (室淐) \\
\hline & $7 \times 10^{-5}(110)$ & \\
\hline $\mathrm{H}_{2}, \mathrm{~N}_{2}, \mathrm{CO}(15)$ & $\sim 0$ & (室 温) \\
\hline
\end{tabular}

ベるので，ここでは残留ガス成分の GaAsへの付着原 数について述べる。

一般に真空装置内部に残される残留ガス成分中で最 も多いるのは $\mathrm{H}_{2} \mathrm{O}$ である(7)。特に十分なベークアウ トができない場合はこの傾向が著しい。ての他に $\mathrm{O}_{2}$, $\mathrm{CO}, \mathrm{N}_{2}, \mathrm{H}_{2}$ などが考えられる。 $\mathrm{CO}, \mathrm{N}_{2}, \mathrm{H}_{2}$ などは第 1 表に示机るように付着保数は〜0で，て机らの残 留ガスについてはあまり気在配らなくてもよいととが わかる。 $\mathrm{O}_{2}$ の吸着(化学吸着であれば表面の酸化子考 えてよい) は面方位注っって暴なり，(III) 面で最む 大きい。このことは O-As の結合エホルギー114kcal/ mol が O-Ga の結合エネルギー $75 \mathrm{kcal} / \mathrm{mol}$ に比べ て大きいとと加ら香予想される。

$\mathrm{H}_{2} \mathrm{O}$ の付着係数は未知であるが，ある程度の確率 で解離吸着するすのと思わ机る。Al などの蒸着㮩お いて蒸着中に異常に $\mathrm{H}_{2}$ 加增加するととか知られてお り，等者ら香 $\mathrm{Ge}$ の蒸着でこの傾向を見いだしている。 $\mathrm{O}_{2}$ は GaAs K混入されると deep trap として働き， 他の不繦物をドープして伝導形を制御するのが困難と なる。したがって，残留ガス中の $\mathrm{H}_{2} \mathrm{O}$ 林よび $\mathrm{O}_{2}$ 成 分は極力減少させなければならない。從来の三温法に 加わって分子線法を用いるととにより $\mathrm{O}_{2}$ の混入をで きるだけ扔さ兑，従来の蒸着膜よりも伝導形の制御放 容易になったととは前報(5)で報告した。 $\mathrm{H}_{2} \mathrm{O}$ の除去 法としては，十分なべークアウトとマイスナトラップ

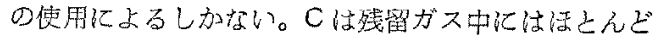
ないか，炭素化合物の解離吸着によって表画付付着す ると，イオンボンバードメントなどの強力な方法でな いと除去できない量ので, $\mathrm{CO}, \mathrm{CO}_{2}$ も減少させるのが 望志しい。

\section{3. 实験ならびに結果}

〈3.1〉 GaAs 結晶の成長 使用した蒝着系など については，前報で報告したので本論文では省略する

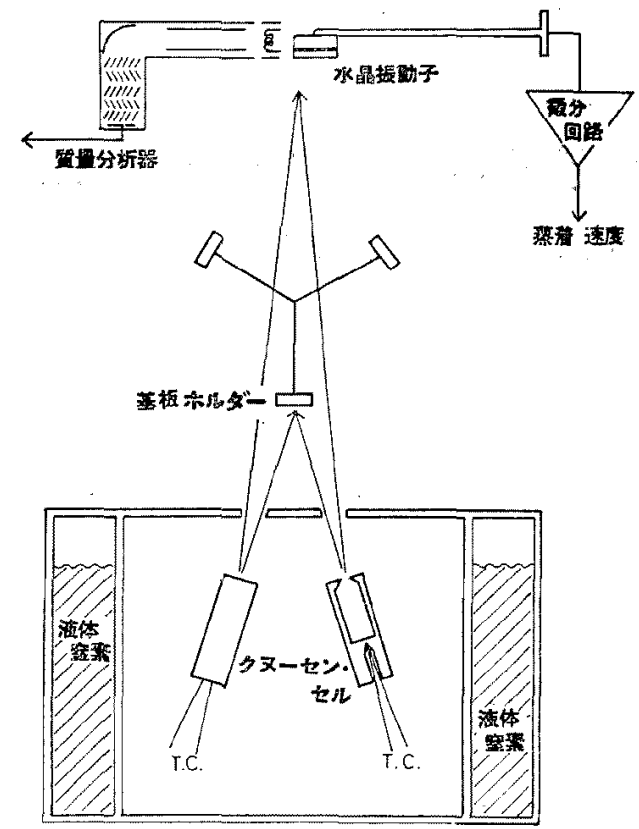

第 1 図 実歌装置の概略

Fig. 1. Schematic of experimental apparatus.

加，已の概路图を第1図に示す。高其空系は1回の running time が長いので, 1 回の排気で 3 個の試料が 形成できるようにしてある。排気系はオイルフリーな ゲッタイオンポンプ拈よびチタニウムサブリメーショ ンポンプを用い,バックグランドは 10-9 Torr であ る。蒸発源および蒸発室, 蒸着手順については前報 のと掠りである。

蒸発源加らビーム状汇なって皟出してくる Ga，As およびドーパントの分子線的基板化到達すると同㭙に 膜原扰よび蒸着速度モ二夕用の水晶振動了の表面上質 量分析計のガス導入口にも達するようになっている。

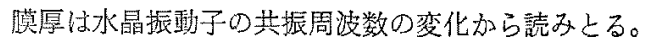
$1 \mathrm{kHz}$ の変化は $\mathrm{G}_{\mathrm{a}} \mathrm{As}$ の場合 $300 \AA$ の膜厚汇相当す

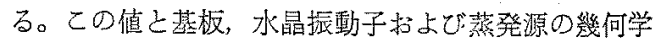
的な配置から計算によって膜厚を知ることができる。 水晶振動子は水冷されているた的に，成長時の甚板温 度では付着しないドーパントす付着するのでドーパ ントの分子楾强度が藷しく大きい乞きは㑭倳を生ずる

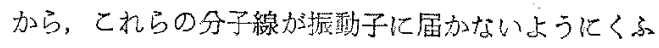
うしてある。

螅量分䉼計は 4 極子形で，質量数 1 300 までの残 留ガスの分析ができる。第2 図侄型的な残留ガスス ペクトルの測定結舆を示す。乙扎は液体空素の冷却卜

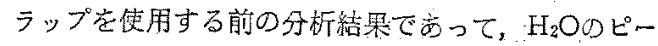




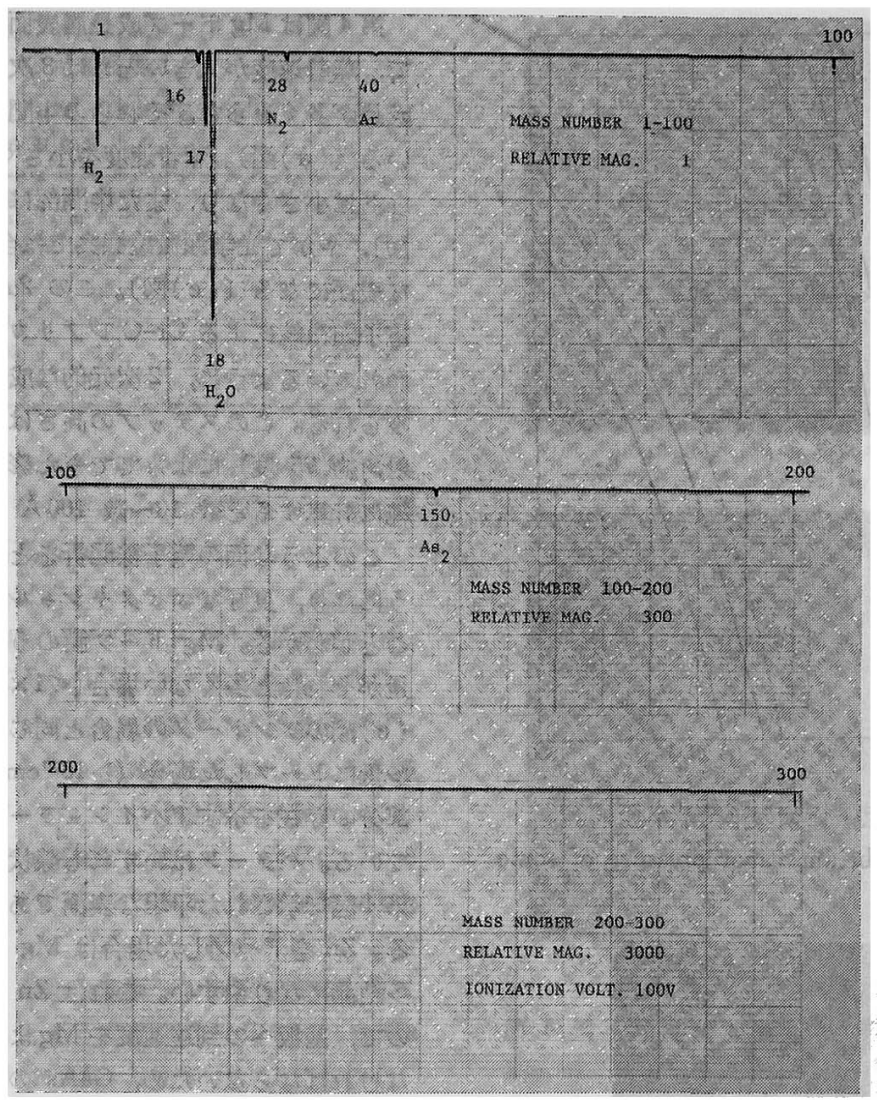

第 2 図 残留ガススペクトルの一例

Fig. 2. Typical mass spectrum of residual gases.

クは冷却トラップを用いることによって著しく減少す る。50 以上の質量数の大きなピークは分析計 (日電バ リアン製 NAG-530)の感度を最大にしても $\mathrm{As}_{2}$ を除 いてほとんご㭘出されない。蒸着時はこ机に $\mathrm{Ga}$ およ び As のピークが加和る。これらのピークの出力を堌 幅して蒸発源温度制御に用いることも可能であるが， 質量分析計の安定度が十分でなく，現段階では蒸発源 温度を熱電対で検出して蒸発分子流制御を行なってい る。

すでに報告したように(5)，GaAs(111) 面を基板と したアンドープホモエピタキシャル層は，基板温度が 約 $440^{\circ} \mathrm{C}$ で双晶構造を伴って形成され，530号では双 晶構造のない，表面が滑らかなエピタキシャル層が形 成される。

〈3.2〉不純物のドーピング 伝導形を制御する ために同時蒸着による不純物ドープを行なった。用い た不純物は $\mathrm{Sn}(n), \mathrm{Zn}(p), \mathrm{Mg}(p)$ である。付着係数 はドープした不純物が完全にイオン化していると考え
て，成長層のキャリア濃度と不純物分子の基板への到 達速度加ら求めた。不純物分子の基板への到達速度 は, 蒸発源の幾何学的配置之蒸発源温度加計算に上 って求めることができる。

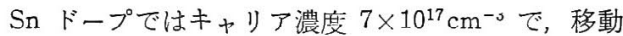
度が $1,100 \mathrm{~cm}^{2} \mathrm{~V}^{-1} \mathrm{~s}^{-1}$ 程度のあのが得られた。この移 動度の值は同じキャリア濃度のバルク GaAs の 1/2 弱 で, 従来の真空蒸着膜 $\left(10^{-2} \mathrm{~cm}^{2} / \mathrm{V} \cdot \mathrm{s}\right)^{(20)}$ 上比べると良 好な值である。キャリア濃度と $\mathrm{Sn}$ と $\mathrm{Ga}$ の基板への 到達比は 1 対 1 の対応を示し, Sn の付着係数は〜1 である。

$\mathrm{GaAs}$ への $\mathrm{p}$ 形ドーパントとしては $\mathrm{Ge}, \mathrm{Mg}, \mathrm{Zn}$, $\mathrm{Cd}$ などが考えられる。第 3 図に示すように $\mathrm{Mg}, \mathrm{Zn}$, $\mathrm{Cd}$ はその蒸気圧が高いので，第2 章で述べたように 付着係数は小さい之考えら机る。このことからすると Geのほうがドープしやすいことになるが，Ge は両性 不純物であり，報告 ${ }^{(9)}$ されているように $\mathrm{p}$ 形ドーパン トとして用いる場合は Ga rich の状態を保たねばなら 


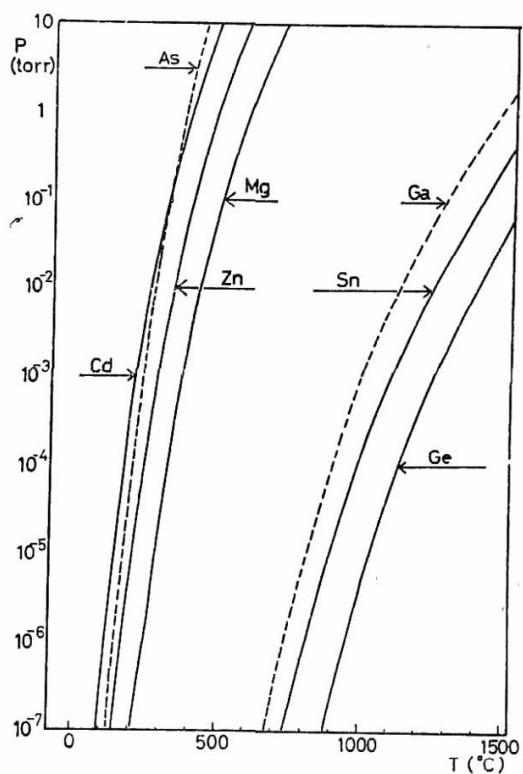

第 3 図元素の平衡蒸気圧

Fig. 3. Equilibrium vapor pressure of some elements.

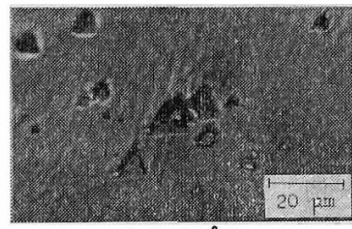

(a) $50 \AA / \mathrm{s}$

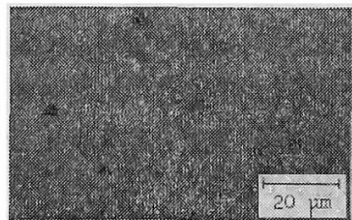

(b) $13 \AA / s$

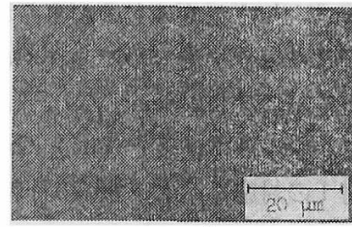

(c) $2 \AA / \mathrm{s}$

第 4 図成長表面の光学顕微鏡および 電子顕微鏡写真

Fig. 4. Photo- and electron-micrographs of surface of grown layers.

ないとと，および補償されるために不紋物の利用効率 が落ちるととなどの理幽より，本実験では $\mathrm{Zn}, \mathrm{Mg}$ を用いた。
第 4 図は Mg ドープ成長層表面の状態を示したもの で，蒸着速度が大きいときは 3 次元的なピラミッド状 成長が多くみられ，それらの中間部む大きく波打って いる〔( a )図〕。蒸着速度を小さくしてゅくとピラミ ッドは小さくなり，また中間部は平坦になって〔(b) 図了, やがて光学顕微鏡観察では全く特徵のない平坦 な表面になる〔(c)図〕この $2 \AA / \mathrm{s}$ の場合の写真は 電子顕微鏡による $\mathrm{Cr}-\mathrm{C} レ$ レフリカ像である。写真に現 わ机てるよう代，2次元的な成長を示すステップが みられる。このステップの高さは $\mathrm{Cr}$ の斜め蒸着（入 射角約 75 度) によってできた影の部分の長さから単 純化計算すると数 10 数 $100 \AA$ 程度である。

このような面の電子線回折をとると第 5 図に示すよ うになり，良好なエピタキシャル層が形成されている

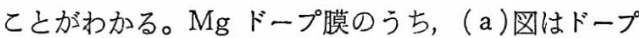
量がそれほど多くない場合 $\left(<1 \times 10^{18} \mathrm{~cm}^{-3}\right)$ であって, （c）図のアンドープの場合と同じであるが，（b）因は 多量にドープした場合 $\left(>10^{20} \mathrm{~cm}^{-3}\right)$ で，多結晶性の 部分の存在を示すデバイシュラー環がわずかに現われ ている。パターンはいずれあ線状 (streaks) であって， 第 4 図で示された平坦な表面であるととを裏づけてい る。Zn をドープした場合は $\mathrm{Mg}$ よりも結晶性は劣り 多結晶になりやすい。乙れは $\mathrm{Zn}$ の付着係数が小さい ので，基板への到達速度を $\mathrm{Mg}$ よりもかなり大きくし なければならないため，GaAs の単結晶化が損なわれ るためであろうと考えている。すなおち，多䡄に入射

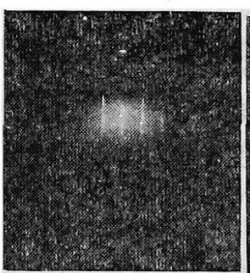

(a)

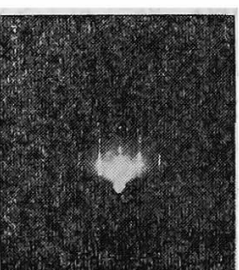

(b)
( $\mathrm{Mg}$ dope)

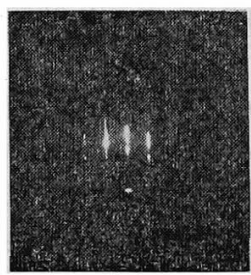

(c)

(undope) (110) azìmuth

第 5 図 電子線回折パターン

Fig. 5. High energy electron diffraction patterns. 
第 2 表 成長膜の $n, \rho, \mu$ およびドーパント の付着係数

Table 2. $n, \rho, \mu$ and sticking coefficient of dopant for some films.

\begin{tabular}{|c|c|c|c|c|c|}
\hline $\begin{array}{l}\text { 武料番号 } \\
\text { (No.) }\end{array}$ & $\begin{array}{l}\text { シーパ } \\
\text { シト }\end{array}$ & $\begin{array}{l}\text { 抵抗率 } \\
(\Omega \cdot \mathrm{cm})\end{array}$ & $\begin{array}{l}\text { 移勤度 } \\
\left(\mathrm{cm}^{2} \mathrm{~V}^{-1} \mathrm{~s}^{-1}\right)\end{array}$ & 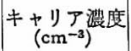 & 付着係数 \\
\hline 1 & $\mathrm{Zn}_{\mathrm{n}}$ & 0.51 & 15.6 & 1. $3 \times 10^{18}$ & $5 \times 10^{-7}$ \\
\hline 6 & $\mathrm{Mg}$ & 0.0050 & 22.5 & $5.6 \times 10^{19}$ & $1.5 \times 10^{-4}$ \\
\hline 7 & $\mathrm{Mg}$ & 0.063 & 104 & $9.5 \times 10^{17}$ & $2.0 \times 10^{-4}$ \\
\hline 8 & $\mathrm{Mg}$ & 0.0093 & 14 & $4.8 \times 10^{19}$ & $2.0 \times 10^{-3}$ \\
\hline 9 & $\mathrm{Mg}$ & 0.0074 & 102.5 & $8.2 \times 10^{18}$ & $1.4 \times 10^{-4}$ \\
\hline
\end{tabular}

する $\mathrm{Zn}$ 分子は $\mathrm{Ga}$ および As の表面移動を妨げるこ とが考えられるし，揮発性の $\mathrm{Zn}$ の蒸気を真空中に噴 出させることは超高真空蒸着を困難にする。

第 2 表に得られた試料のいくつかについて抵抗率, キャリア濃度, 移動度, ドーパントの付着係数を示す。

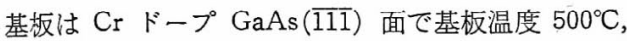
蒸着速度は $5 \AA / \mathrm{s}$ である。前報 ${ }^{(5)}$ で基板温度 $530^{\circ} \mathrm{C}$ 以上で良好なエピタキシャル層が形成されることを報 告したが，今回はドーパントの付着係数が小さいとと を考慮して，少し抵い $500^{\circ} \mathrm{C}$ に選んだ。膜厚は No. 8 の $800 \AA$ を除いて $0.5 \mu \mathrm{m}$ である。付着係数は $\mathrm{Mg}$

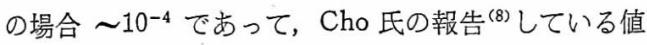
$10^{-5}$ より大きいが， $\mathrm{Mg}$ の基板への到達速度の計算に 入る誤差を考虑するとそう大きな違いではない。Zn については $5 \times 10^{-7}$ で $\mathrm{Mg}$ より 3 けたほど小さく， 蒸気圧の傾向から予想される值を示している。No. 8 の試料の付着係数が著しく大きく現われることの説明 として，この試料は膜厚が他の試料と比べて薄いので 基板からの不純物搪散が考えられる。すなわち，蒸着 開始直前に基板を真空中で $580 \sim 620^{\circ} \mathrm{C}$ 程度に加熱し て表面の清浄化を行なっているが，一般に Cr ドープ $\mathrm{GaAs}$ 結晶中には他の不純物が相当量含まれていると いわれており，この不純物の一部が表面に拡散するこ よが考えられる。また成長層は基板表面に近い部分ほ ど結晶性が劣るために，欠陥が発生しやすく，てれに 不䋨物が捕えられるととにより付着係数が增大してい ることす考えられる。

移動度およびキャリア濃度の温度依存性は, 室温か ら低温になるに從い移動度は除々に増加し，たとえば No. 7 の試料では $150 \mathrm{~K}$ 付近で約 $400 \mathrm{~cm}^{2} \mathrm{~V}^{-1} \mathrm{~s}^{-1}$ と なって最大となる。同時にキャリア濃度は減少し $4 \times$ $10^{16} \mathrm{~cm}^{-3}$ となる。

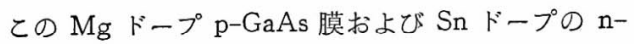
$\mathrm{GaAs}$ 膜を用いて形成した薄膜ダイオードの $I-V$ 特 性を第 6 図に示す。（a 図仙 $\mathrm{n}$ 形基板之の接合，(b) 図は成長層中に形成した接合によるものである。（a）

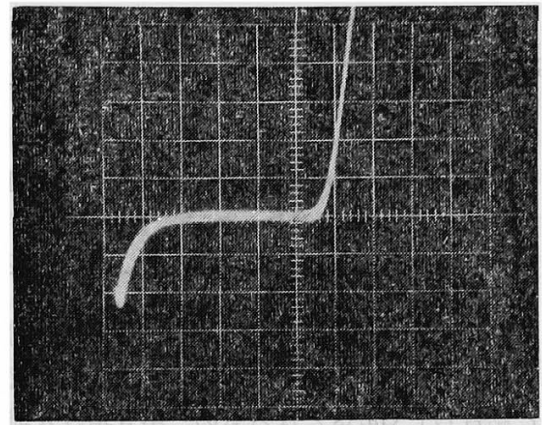

p-GaAs $(\mathrm{Mg})$ film on $\mathrm{n}-\mathrm{GaAs}(\mathrm{Si})$ sub (a) $V_{e r}: 0.002 \mathrm{~mA} / \mathrm{div}, H_{0 r}: 1.0 \mathrm{~V} / \mathrm{div}$

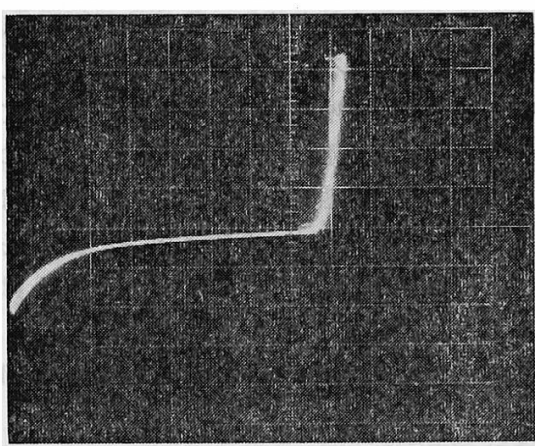

$\mathrm{p}-\mathrm{GaAs}(\mathrm{Mg})$ film on $\mathrm{n}-\mathrm{GaAs}(\mathrm{Sn})$ film

(b) $V_{e r}: 10 \mathrm{~A} / \mathrm{div}, H_{0}: 1.0 \mathrm{~V} / \mathrm{div}$

第 6 図 $\mathrm{Mg}$ ドープ薄膜ダイオードのI-V特性

Fig. 6. $I-V$ characteristics of $\mathrm{Mg}$ doped thin film diodes.

図では逆方向漏れ電流の小さな接合が形成されてい る。（b 図は薄膜のキャリア榩度が高いため, 逆方向 の降伏が明瞭でない。

\section{4. 結果の検討}

第 2 章でも述べたように，分子線法で不純物をドー プするにはその付着係数が大きな問題になる。したが って，与えられた結晶について不純物の付着係数がど のくらいになるかあらかじめ予测できることが望まし い。付着係数とは表面に飛来した原子あるいは分子の うち，表面に捕われて固体の一部となるものの割合で ある。したがって，化学吸着がその性質の大部分を支 配するが，吹着の化学結合の性質についてはほとんど わかっていない。そこで, ここでは吸着の化学結合の エネルギーを適当な方法で見積って, 吸着状態の不純 物原子の密度に対す万速度方程式在たて, GaAs への 同時蒸着による不純物ドープについて考察し, あわせ て実験結果との比較検討を行なう。

GaAs の母体結晶の成長については，その成長速度 は Ga の入射束によって律速されているので, 吸着状

Vol. 94-A, No. 9 
態の $\mathrm{Ga}$ 密度の速度方程式をたてれば良い(6)。添字 1

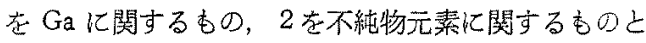
して速度方程式は

$$
\begin{aligned}
& \frac{d n_{1}}{d t}=-\frac{n_{1}}{\tau_{1}}-n_{1} k_{1} F_{\mathrm{As}}+F_{\mathrm{Ga}}+\Gamma \\
& \frac{d n_{2}}{d t}=-\frac{n_{2}}{\tau_{2}}-k_{2} n_{2}+F_{D}+\Delta \ldots \ldots .
\end{aligned}
$$

となる。とこで，（1）式の第 1 項は表面滞在時間 $\tau_{1}$ で脱着してゆく $\mathrm{Ga}$ 原子，第2項は入射してくる As 分子と粕合して GaAs となるるの，第 3 項は入射して くる Ga 原子，第 4 項は GaAs 0 分解によって生成さ れるあのを示す。また(2)式の第 1 項は同じく表直滞 在時䦓 $\tau_{2}$ で脱着する分子，第 2 項は不純物よして結 晶中にくり远ま机てゆくもの，第3愐は入射してくる 屯の，第4項杜成長尿加ら㹡散して出てくるすのを示 す。第 4 項は定常状態で成長させているときには算視 できるが，p-nあるいはへテロ接合の多置構造を形成 する場合には考慮しなくてはならない。 $k_{1}, k_{2}$ はそ机 ぎれ我来した Ga 分子加 As と結合して GaAs にな る蛙合㧍よび表面に存在する不純物が結晶中に組み込 まれる割含を表わす。

(1)式拈よび(2)式加ら定甞的な表面密度が求まり それを机

$$
\begin{aligned}
& n_{1}=\frac{F_{\mathrm{Ga}}+\Gamma}{1 / \tau_{1}+k_{1} F_{\mathrm{As}}} \\
& n_{2}=\frac{F_{D}+\Delta}{1 / \tau_{2}+k_{2}} \ldots \ldots
\end{aligned}
$$

亡なる。不齐物の付着係数 $S_{2}$ は

$$
S_{2}=\frac{k_{2} n_{2}}{F_{D}} \simeq \frac{1}{1 / k_{2} \tau_{2}+1}
$$

となる。ここでは(4)式のムは小さいとして無視し た。 $k_{2} \tau_{2} \ll 1$ の揘含には $S_{2} \approx k_{2} \tau_{2}$ となる。一方，ド ーピング密度 $P$ 踣鼠中にくり这まれる Ga とドー パントの比で決まり

$$
P=\frac{k_{2} n_{2}}{k_{1} n_{1} F_{\mathrm{As}}} B=\frac{k_{2} n_{2}}{d}
$$

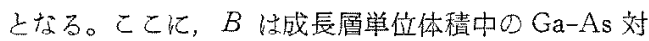
の数，dは蒸着速度であって，奏测によって容易に決

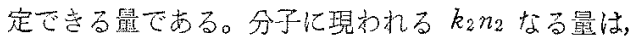
GaAs O n 仅ドーパントである Sn, Si, Ge のような

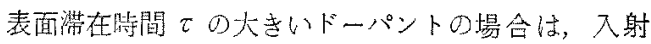

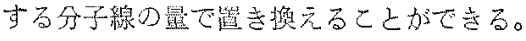

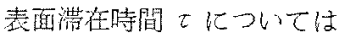

$$
\tau=\tau_{0} \exp \left(\frac{E_{b}}{k T}\right)
$$

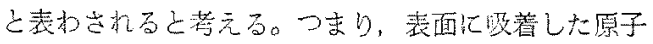

はて。なる周期で表面垂直方向に㧔動しており，この

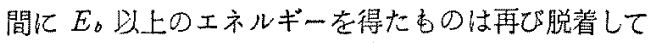
ゆくと考える。GaAs上の各種元素の吸着に対する

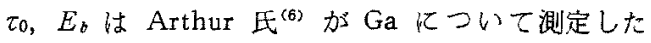
ほ加は位とんよ゙未知である。そこで，てについては Arthur氏の Ga における值 $1.5 \times 10^{-14} \mathrm{~s}$ (GaAs(们)

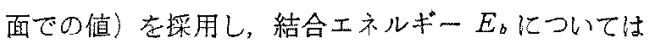

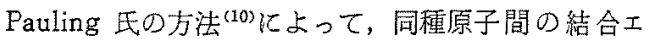
ネルギーと電気陰性度加ら次式を用いて求める。

$$
E_{A-B}=\frac{1}{2}\left(E_{A-A}+E_{B-B}\right)+23\left(x_{A}-x_{B}\right)^{2}
$$

ここに， $E_{A-A}, E_{B-B}$ はてれでれ $A$ 求よひ $B$ 分子単 体での結合エネルギー， $x_{A}, x_{B}$ はそれぞれの電気陰

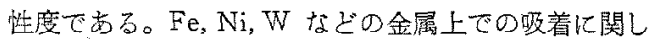
て，(8)式は央唤値とかなり一致した結累を示してい 万。

ここでは，港字 Aに Gaあるいは As, B K不純物元 素老あててそれぞれの間の結合エネルギー $E_{A-B}$ 定求 め，ての值の大きいほうの組合せが吸着の過過を律速 していると考えて大さい涪うの值を採用する。第 3 表

\begin{tabular}{|c|c|c|c|}
\hline 元 菜 & 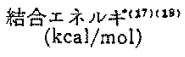 & 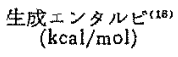 & 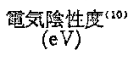 \\
\hline $\mathrm{Ga}-\mathrm{Ga}$ & 33 & 66.0 & 1.6 \\
\hline$A s-A s$ & 32.1 & 60.64 & 2,0 \\
\hline Ge-Ge & 65 & 90.5 & 1.8 \\
\hline $\mathrm{Mg}_{\mathrm{g}-\mathrm{Mg}}$ & 6.8 & 35.9 & 1.2 \\
\hline $\mathrm{Zn}-\mathrm{Zn}$ & 6 & 31. 19 & 1.6 \\
\hline$S n-S n$ & 46.7 & 72.0 & 1.8 \\
\hline
\end{tabular}
に各種の元菡について結合エネルギー $E_{b}$ ，生成エン タルピー $\Delta E_{f}{ }^{0}$, 電気除性度 $x$ の值示示。 $\mathrm{Mg}-\mathrm{Mg}$ の結合エネルギーの值は未知であるので，生成エンタ

第 3 表 結合エネルギー，生成エンタルピー および電気陰性度

\begin{tabular}{|c|c|c|c|}
\hline 組合せ & $\mid \begin{array}{l}\text { 結合土衣ル } \\
-(\mathrm{kcal} / \mathrm{mol})\end{array}$ & 合金乙Zの融点 & 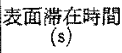 \\
\hline $\mathrm{Ga}-\mathrm{Mg}$ & 23.6 & $\mathrm{Mg}_{5} \mathrm{Ga}_{2}$ & $8 \times 10^{-8}$ \\
\hline As-Mg & 34.3 & $\mathrm{Mg}_{3} \mathrm{As}_{2}$ & $9 \times 10^{-5}$ \\
\hline $\mathrm{Ga}-\mathrm{Zn}$ & 19.5 & 合金つくら放拱罚点 $25^{\circ} \mathrm{C}$ & $6 \times 10^{-9}$ \\
\hline$A s-Z n$ & 22.8 & $1,015^{\circ} \mathrm{C}$ & $5 \times 10^{-8}$ \\
\hline $\mathrm{Ga}-\mathrm{Sn}$ & 40.8 & & $6 \times 10^{-3}$ \\
\hline$A s-S n$ & 37.3 & & $6 \times 10^{-4}$ \\
\hline $\mathrm{Ga}-\mathrm{Ge}$ & 50.4 & & 2.0 \\
\hline As-Ge & 49.5 & & 1.2 \\
\hline
\end{tabular}

Table 3. Binding energy, enthalpy of formation and electronegativity values.

第 4 表 いくつかの組合せの結合エネルギー および䒾面汸在時間

Table 4. Binding energy and surface resident time for several systems. 
ルピーに比例すると考えて $\mathrm{Zn}-\mathrm{Zn}$ の值汃ら計算した あのである。これらから（8)式によって計算した結合 エネルギーおよひをれらの組合せが規則合金を形成す る埸合仕その䛲点を第 4 表に示す。

また， $\tau_{0}$ 亿 $1.5 \times 10^{-14} \mathrm{~s}$ を用いて $500^{\circ} \mathrm{C}$ の暘合 について計算したての值を同時に示してある。第 4 表 の第1列の結合エネルギーの大小の傾向は，第 2 列の 合金の融点の大小の傾向亡良く一致している。Ge 以 外はて《1であるので（2）式の $k_{2}$ の值は不明であ

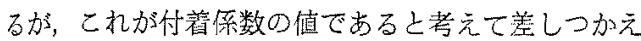
ない。誨算により求好たは $\mathrm{Sn}$ 亡 $\mathrm{Zn}$ で少し小さ

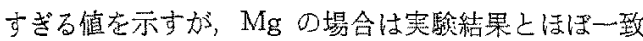
していると考えて良い。

$\mathrm{Mg}, \mathrm{Zn}$ ではともにAs との結合が噍く，てれが吸 着の過程を律速している。 GaAs 上入の $\mathrm{Zn}$ の吸着の 報告 (12)です初期の1単原子層以下の吸着では $\mathrm{Zn}-\mathrm{As}$ の形で存在しているこ上を示兴している。Sn の缹合 に実験の結果 $(\sim 1)$ との墥いが大きずることについ てば現在まだわかっていない。

$\mathrm{Mg}, \mathrm{Zn}$ では第 4 表の結果のように付着係数が小さ く，同時蒸着によるドーパントとしては適当でない。 付着係数が大きくなるためには，(8)式からわかるよ 引に不純物元紊自身の結合エネルギーが大きく，また Ga あるいはAs Lの電気险性度の差が大きいほど良 い。第 4 表で As-Mg $の$ 組合せの $\tau$ 加比較的大きい のは，As と Mg の電気除性度の差怔大きいことによ っている。そこで, 現在問題となっている p 形ドーパ ントで結合エネルギーが大きく，電気除性度の差の大 きい元素を拾い出してみると第 5 表のようになる。こ のうちC-Cは理想的であり，実際に結晶のIMA(Ion Micro Analyzer) 分析老行なうと, 注意深く作った結 晶でも多量の炭素が検出される。しかし，大部分恃電 気的任不活性となっているのて，ドーパントとしてい 间いていない。その他の系についてて計算してみる

第 5 表 綕合エネルギー，電気陰性度斿よび $500^{\circ} \mathrm{C}$ 儿扣讨る平衡蒸気在

Table 5. Binding energy, electronegativity and equilibrium vapor pressure at $500^{\circ} \mathrm{C}$.

\begin{tabular}{|c|c|c|c|}
\hline 元 菉 & $\begin{array}{l}\text { 結弇エ衣ルギ(ur) } \\
\text { (kcal/mol) }\end{array}$ & $\begin{array}{c}\text { 電気隐性店(10) } \\
(\mathrm{eV})^{(10)}\end{array}$ & 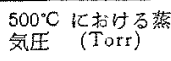 \\
\hline $\mathrm{Li}-\mathrm{Li}$ & 26.7 & 1.0 & $5 \times 10^{-5}$ \\
\hline $\mathrm{C}-\mathrm{C}$ & 114 & 2.5 & - \\
\hline$M n-M n$ & 21 & 1.5 & $8 \times 10^{-8}$ \\
\hline $\mathrm{Com}_{0}$ & 39 & 1.8 & $5 \times 10^{-12}$ \\
\hline
\end{tabular}

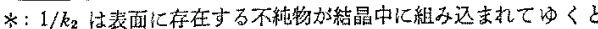

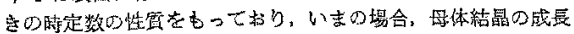
速既が 1 monolayer/s程度であるので， $k_{2} \sim 1$ として考えて 夻大き旅差はない。
と $\mathrm{Li}: 15 \mathrm{~s}, \mathrm{Mn}: 3 \times 10^{-5} \mathrm{~s}, \mathrm{Co}: 4.5 \times 10^{-4} \mathrm{~s}$ となり, Li,Co の $\tau$ が $\mathrm{Mg}$ より屯大きい。特に $\mathrm{Li}$ はこの值 加ら求めると付着係数は～1となる。 Li は GaAs 中 での拡散係数が大き? $\left(500^{\circ} \mathrm{C}\right.$ で $\left.1.6 \times 10^{-7} \mathrm{~cm}^{2} / \mathrm{s}^{(13)}\right)$,

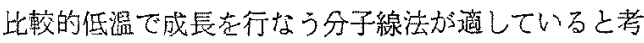

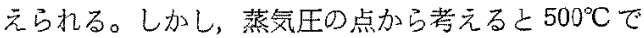
$\mathrm{Mg}$ の蒸気圧が $3 \times 10^{-3}$ Torr であるのに対して，Li は $1 \times 10^{-4}$ Torr $の$ 程度であるから，それによ゙付着倸 数が大きくなるか路わしい。とれk対して Mn, Co は

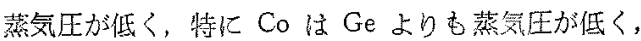
$\tau$ の䛨算結果む $\mathrm{Mg}$ より1けた近く大きく有望であ ると思和召。

\section{5. むすび}

$\mathrm{GaAs}$ の同時蒸眻によるn形ドーパントとしては， Si，Ge, Sn 垃容易にドープされ得る向のがあるが， p形ドーパントとしては $\mathrm{Mg}, \mathrm{Zn}, \mathrm{Cd}$ な゙付著䋆数口 小さな本のしかない。闻性不純紧では Ge のみがp形 にあドープされると報告されている(9) 本研究ではト 一プされた不純物老効率良く用いることを衫えて $\mathrm{Mg}$ ， Znについてドーピングを元ない，付着係数䚮予想さ れた值を示すことを磼かるた。ドーパントししては，

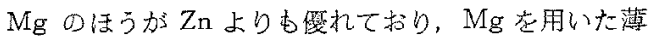

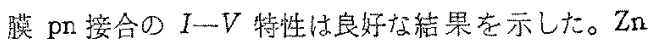
如付着係数が小さいために基板への到達速度を大きく しなけ机ならず，母体の結晶性を損ない，笔子線可 折で多多結晶のパターンが多くみられた。

これらのドーパントの付着保数を統一的に报うため に, Pauling 氏の方法により絬合エネルギーを見皘っ 乙表面漁在時間 $\tau$ 計算し，吸着原子密度の速度方程 式加的付着係数 $S$ を求加。大胆心仮定在用いてい るためにその適用に限界はあるが，Mgについての計 算結果はは活淦足できるものであった。

これら它他の元素についても適用して同時蒸着によ わ非ドーパントとしての可能性岩墚った。その結果 Li，Coなどが付着係数が大きく容易にドーブされやす いであるうと推測される。現在，罪験的にこれを確か るること学検討中て苛る。

終わりに，日頃で指盙していただいている本学酒井

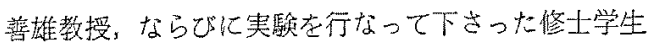
立石和境君ならびに草諭生川烟清和君に感謝いたし ます。

(昭和 49 年 4 月 2 日受付，同 49 年 6 月 19 日再受付) 


\section{文献}

(1) J.R. Arthur, et al. : J. Vac. Sci. Technol. 6, 545(1969)

(2) A. Y. Cho: J. Appl. Phys. 42, 2074 (1972)

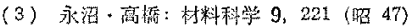

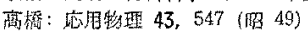

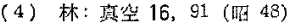

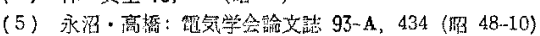

(6) J. R. Arthur, Jr.: J. Appl. Phys. 39, 4032 (1968)

(7) H. L. Caswell: IBM J. Res. Develop. 6, 130 (1960)

(8) A.Y. Cho \& M. B. Panish: J. Appl. Phys 43, 5118 (1972)

(9) A.Y. Cho \& I. Hayashi: J. Appl. Phys. 42, 4422(1971)
(10) L. Pauling: The Nature of the Chemical Bond p. 64 (1960)

(11) D. P. Stevenson: J. Chem. Phys. 23, 203 (1955)

(12) J. R. Arthur: Suaface Sci. 38, 394 (1973)

(13) C.S. Fuller, et al. J. Appl. Phys. 33, 2507 (1962)

(14) R. E. Honig: RCA Rev. 23, 567 (1962)

(15) D. D. Pretzer, et al. : Surface Sci. 4, 265 (1966)

(16) A. U. MacRae: ibid. 4, 247 (1966)

(17) Handbook of Chemistry and Physics ed. by R. C. Weast (Cemical Rubber Co. Ohio U.S. 1968)

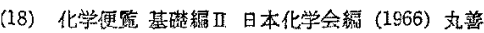

(19) M. Hansen \& K. Anderko: Constitution of Binary Al. loys (1958) MacGraw Hill N. Y.

(20) K. Takahashi: J. Vac. Sci. Technol. 9, 502 (1972) 